\title{
PENGEMBANGAN MODUL MATA KULIAH STRATEGI BELAJAR DAN PEMBELAJARAN PADA FKIP-UNIVERSITAS BATURAJA
}

\author{
Nora Agustina dan Anita Adesti \\ Program Studi Teknologi Pendidikan Universitas Baturaja \\ Email: noraagustina@gmail.com dan anitaadesti@gmail.com
}

\begin{abstract}
Abstrak
Tujuan dari penelitian ini adalah untuk mengembangkan modul pembelajaran yang valid dan praktis pada mata kuliah Strategi belajar dan pembelajaran pada Program Studi Teknologi Pendidikan FKIP Universitas Baturaja. Metode penelitian menggunakan Metode Pengembangan dengan model desain pengembangan produk Rowntree. Pengumpulan data dilakukan melalui (1) uji para ahli (expert) meliputi uji ahli media, ahli desain dan ahli materi, kemudian (2) uji Lapangan meliputi: uji perorangan (one to one), uji kelompok kecil (Small Group) dan Uji Lapangan (field tes), Subjek penelitian terdiri dari 20 orang responden. Berdasarkan hasil penelitian telah dihasilkan pengembangan modul pada mata kuliah Strategi Belajar dan Pembelajaran yang teruji validitasnya. Pengembangan modul yang dihasilkan dari aspek Materi sudah tepat dengan pembelajaran, menggunakan media cetak, gambar yang tepat, dan jelas dalam uraian materi, soal latihan dan soal evaluasi. Dari aspek Desain pembelajaran, Pengembangan modul yang dihasilkan memiliki kesesuaian pendekatan dalam pembelajaran, efektif dan efisien dalam pencapaian kompetensi, sesuai dengan karakteristik sasaran, soal latihan dan soal evaluasi sesuai dengan RPS. Dari aspek Media modul yang dihasilkan memiliki kemenarikan dan kemudahan dalam memahami materi sehingga diharapkan dapat mendorong mahasiswa untuk lebih termotivasi dalam belajar. Jadi dapat disimpulkan bahwa perkuliahan pada mata kuliah Strategi Belajar dan Pembelajaran menggunakan modul dapat meningkatkan aktivitas belajar mahasiswa.
\end{abstract}

Kata kunci : Pengembangan, Modul Pembelajaran, Strategi Belajar dan Pembelajaran

\section{Pendahuluan}

Belajar dapat diartikan suatu proses perubahan yaitu perubahan tingkah laku sebagai hasil dari interaksi dengan lingkungannya dalam memenuhi kebutuhan hidupnya. Perubahan-perubahan tersebut akan nyata pada seluruh aspek tingkah laku, sedangkan pembelajaran pada hakikatnya merupakan proses interaksi antara guru dengan siswa, baik interaksi secara langsung seperti kegiatan tatap muka maupun secara tidak langsung, yaitu dengan menggunakan berbagai media pembelajaran. Didasari oleh adanya perbedaan interaksi tersebut, maka kegiatan pembelajaran dapat dilakukan 
dengan menggunakan berbagai pola pembelajaran. (Warsita, 2008) "Pembelajaran adalah suatu usaha untuk membuat peserta didik belajar atau suatu kegiatan untuk membelajarkan peserta didik".

Menurut (Tjiptiany, As'ari, \& Muksar, 2016) melalui modul, maka mahasiswa mampu menjalani proses belajar yang mendapat informasi, tanpa harus meluangkan tenaga, waktu dan biaya untuk sumber belajar. Modul ditulis dan disusun sedemikian rupa sehingga bahan yang disampaikan dalam kegiatan belajar mengajar selalu terarah kepada tujuan yang ingin dicapai yang telah dirumuskan dengan jelas dan khusus. Modul juga disusun berdasar kebutuhan nyata dalam rangka pembangunan bangsa dan negara. Modul dapat dijadikan sebagai media pembelajaran alternatif, karena isi modul mempunyai ragam bahasa yang berbeda dengan isi buku teks pelajaran yang cenderung monoton.

Untuk mengetahui sejauh mana penguasaan Mahasiswa terhadap pelajaran dapat dilakukan melalui penilaian terhadap kemajuan atau keberhasilan Mahasiswa menguasai materi pelajaran yang diajarkan. Prestasi Mahasiswa akan menunjukan terjadi tidaknya peningkatan penguasaan. Indikator keberhasilan dari penguasaan Mahasiswa terhadap materi pelajaran yang dipelajari adalah kemampuan belajar Mahasiswa yang diwujudkan dalam hasil belajar Mahasiswa yaitu mengetahui garisgaris besar indikator (petunjuk adanya prestasi tertentu) dikaitkan dengan jenjang prestasi yang hendak diungkapkan atau diukur (Muhibbin Syah: 2001). Di samping itu, prestasi Mahasiswa sering digunakan sebagai suatu indikator kemampuan belajar, karena semakin tinggi hasil belajar dalam mata pelajaran tertentu, semakin tinggi tingkat kemampuan belajar dalam mata pelajaran tersebut yang juga merupakan indikator untuk mengukur kualitas pendidikan. (Gani, 2018)

Modul adalah bahan ajar yang disusun secara sistematis dan menarik yang mencakup isi materi, metode dan evaluasi yang dapat digunakan secara mandiri. Menurut (Prastowo, 2011) pembelajaran dengan menggunakan modul bertujuan (1) siswa mampu belajar secara mandiri atau dengan bantuan guru seminimal mungkin, (2) peran guru tidak mendominasi dan tidak otoriter dalam pembelajaran, (3) melatih kejujuran siswa, (4) mengakomodasi berbagai tingkat dan kecepatan belajar siswa, dan (5) siswa dapat mengukur sendiri tingkat penguasaan materi yang dipelajari. 
Agar dalam proses pembelajaran siswa terlibat aktif dan memiliki pengalaman langsung, maka modul harus dikemas dalam pembelajaran berbasis konstruktivis yang memberikan peluang kepada siswa untuk mengonstruksi pengetahuannya sendiri dan menumbuh kembangkan sikap ilmiah,yaitu dengan model pembelajaran inkuiri. Menurut (Dahar, 2011) siswa hendaknya belajar melalui partisipasi aktif dengan konsep-konsep dan prinsip-prinsip agar mereka memperoleh pengalaman serta melakukan eksperimen-eksperimen sehingga mereka menemukan konsep-konsep dan prinsip-prinsip itu sendiri. Siswa juga perlu diberi kesempatan berperan sebagai pemecah masalah seperti yang dilakukan para ilmuwan. Dengan cara tersebut diharapkan siswa mampu memahami konsep-konsep dalam bahasa mereka sendiri.

Menurut (PMPTK, 2008) modul merupakan sebuah bahan ajar yang disusun secara sistematis dengan menggunakan bahasa yang dapat dengan mudah dipahami oleh siswa serta dapat dipelajari secara mandiri tanpa membutuhkan seorang fasilitator dan modul juga dapat digunakan sesuai dengan kecepatan belajar siswa dengan pengertian tersebut maka modul yang baik memiliki lima karakteristik, yaitu self instruction, self contained, stand alone, adaptive dan user friendly. Beberapa hasil penelitian menunjukkan bahwa penggunaan modul pada proses pembelajaran dapat meningkatkan hasil pelajaran (Esmiyati, Haryani, \& Purwantoyo, 2013).

Mata kuliah Strategi Belajar dan Pembelajaran adalah mata kuliah wajib Fakultas Keguruan dan ilmu Pendidikan (FKIP) Universitas Baturaja yang terdiri dari tiga program studi: Pendidikan Sastra dan Bahasa Indonesia, Pendidikan Bahasa Inggris dan Teknologi Pendidikan Komputer dan Informatika. Sesuai dengan analisis kebutuhan ditemukan bahwa belum ada bahan ajar yang praktis yang bisa digunakan oleh ketiga prodi ini secara seragam dalam mata kuliah ini. Untuk itulah diharapkan dengan adanya pengembangan bahan ajar modul ini dapat membantu aktivitas perkuliahan agar lebih baik.

Menurut (Suryosubroto, 1983) Modul sebagai sistem penyampaian dalam proses belajar mengajar telah dijadikan tumpuan harapan untuk mampu mengubah keadaan tersebut menjadi situasi belajar mengajar yang merangsang, yang lebih mengaktifkan murid untuk membaca dan belajar memecahkan masalah sendiri dibawah pengawasan dan bimbingan guru yang selalu siap menolong murid yang mempunyai kesulitan. 
Merujuk pada teori diatas didapat kesimpulan bahwa mengembangkan modul pembelajaran di Program Studi Teknologi Pendidikan FKIP Universitas Baturaja ini dapat memberikan manfaat dalam mencerdaskan peserta didik, dengan kata lain modul pembelajaran ini mampu membantu serta meringankan beban dosen untuk merangsang minat baca, sehingga kegiatan pembelajaran dapat lebih efisien, relevan, dan efektif. Atas dasar inilah peneliti melakukan penelitian pengembangan bahan ajar modul ini guna mendukung proses pembelajaran agar lebih baik lagi.

\section{Metode Penelitian}

Lokasi penelitian adalah tempat dimana penelitian ini dilakukan. Lokasi penelitian ini di Program Studi Teknologi Pendidikan FKIP-Unbara, yang beralamat di Jl. Jl. Ratu Penghulu No. 02301 Karang Sari. Baturaja-32116 OKU Sumsel, Subjek penelitian pengembangan ini adalah seluruh Mahasiswa/i semester 2 kelas A.2.1 Program Studi Teknologi Pendidikan FKIP-Unbara yang berjumlah 20 orang.Metode penelitian pada penelitian ini adalah penelitian pengembangan (Development Research). model desain pengembangan produk Rowntree. Pada model produk seringkali diawali tiga tahap yakni perencanaan, pengembangan dan evaluasi. Pada tahap evaluasi peneliti akan menggunakan evaluasi formatif Tessmer, dengan alur pelaksanannya seperti gambar 1 berikut:

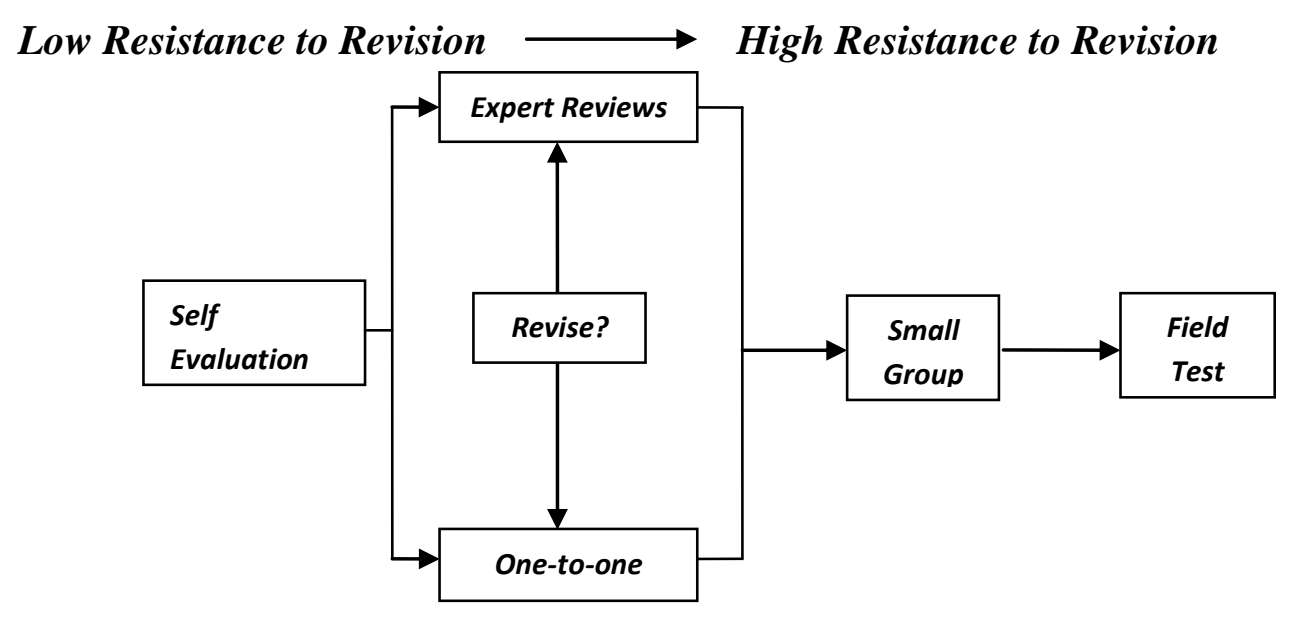

Gambar 1. Alur desain (formative evaluation) Tessmer 
Pada tahap evaluasi model Tessmer (Zulkardi, 2002) menjelaskan berdasarkan alur desain formative evaluation maka pada penelitian ini peneliti akan melakukan self evaluation, dilanjutkan dengan tindakan expert review, dan one-to-one lalu dilakukan small group evaluation dan field test evaluation. Adapun prosedur yang dilakukan dalam penelitian ini adalah mengkombinasikan prosedur antara model pengembangan Rowntree dan tahap evaluasi formatif Tessmer.

\section{Hasil dan Pembahasan}

\section{A. Hasil}

\section{Evaluasi dan Revisi}

Evaluasi dan revisi dilakukan menggunakan model evaluasi formatif (Wedman \& Tessmer, 1993) dengan lima tahapan yaitu: evaluasi diri, evaluasi ahli, evaluasi satu-satu, evaluasi kelompok kecil dan ujicoba lapangan.

\section{Evaluasi Diri (Self Evaluation)}

Pada tahap ini peneliti melakukan evaluasi terhadap prototipe pengembangan modul yang dihasilkan. Evaluasi dilakukan untuk melihat validitas produk menurut peneliti dan ada perbaikan pada beberapa teks yang perlu diperbaiki penulisannya Prototipe yang sudah jadi selanjutnya disebut sebagai prototipe I.

\section{Evaluasi Ahli (Expert Evaluation)}

Evaluasi ahli (expert evaluation) terhadap prototipe I ini dilakukan dengan validasi oleh tiga orang validator. Hasil validasi terhadap seluruh aspek yang dinilai, diperoleh nilai rata-rata,dengan kategori valid. Untuk validasi materi diperoleh nilai rata-rata 4,5 dengan kategori valid, validasi desain pembelajaran diperoleh rata-rata 4,5 dengan kategori valid dan 4,2 untuk validasi media. Nilai rata-rata dari 3 aspek penilaian tersebut adalah 4,4 dengan kategori valid. Komentar ketiga validator terhadap prototipe I disajikan dalam tabel 1 berikut: 
Tabel 1 Nama Validator pengembangan modul dan Saran untuk Prototipe I

\begin{tabular}{|c|c|c|c|c|}
\hline No. & $\begin{array}{c}\text { Nama } \\
\text { Validator }\end{array}$ & Indikator & saran & Tindak lanjut \\
\hline 1 & $\begin{array}{l}\text { Eriyanti, } \\
\text { M.Pd }\end{array}$ & $\begin{array}{c}\text { Aspek } \\
\text { Materi } \\
\text { (content) }\end{array}$ & $\begin{array}{l}\text { Perdalam dan perluas materi } \\
\text { sesuai dengan kebutuhan } \\
\text { yang ada pada RPS mata } \\
\text { kuliah Strategi Belajar dan } \\
\text { Pembelajaran }\end{array}$ & $\begin{array}{l}\text { Saran diterima } \\
\text { dan dilaksanakan }\end{array}$ \\
\hline 2 & $\begin{array}{l}\text { Yelmi } \\
\text { Yunarti, M.Pd }\end{array}$ & $\begin{array}{l}\text { Desain } \\
\text { Pembelaja } \\
\text { ran } \\
\text { (Contruct) }\end{array}$ & $\begin{array}{l}\text { 1. Pada desain gambar yang } \\
\text { di pilih disesuaikan } \\
\text { dengan materi } \\
\text { 2. Tambahkan variasi soal } \\
\text { pada evaluasi }\end{array}$ & $\begin{array}{l}\text { Saran diterima } \\
\text { dan dilaksanakan }\end{array}$ \\
\hline 3 & $\begin{array}{l}\text { JokoKuswant, } \\
\text { M.Kom }\end{array}$ & $\begin{array}{l}\text { Aspek } \\
\text { Media } \\
\text { (lay out) }\end{array}$ & $\begin{array}{l}\text { Tambahkan sumber gambar } \\
\text { yang diambil dari internet }\end{array}$ & $\begin{array}{l}\text { Saran diterima } \\
\text { dan dilaksanakan }\end{array}$ \\
\hline
\end{tabular}

Berdasarkan pada tabel 1 dapat dijelaskan bahwa prototipe yang dihasilkan sudah memenuhi kriteria, namun diperlukan beberapa revisi. Saran-saran dari ahli tersebut dijadikan masukan untuk revisi prototipe pertama. Revisi prototipe disebut prototipe I. Prototipe II dikembangkan berdasarkan dari masukanmasukan yang diberikan validator pada Prototipe I. Bagian-bagian yang perlu diperbaiki adalah pengayaan materi serta gambar-gambar yang dapat menyebabkan kekeliruan pemahaman, dan penambahan gambar-gambar yang diperlukan untuk menanamkan konsep dalam pembelajaran. Setelah dilakukan perbaikan, maka prototipe dinyatakan telah valid dan evaluasi dapat dilanjutkan ke tahap selanjutnya.

\section{Evaluasi Satu-Satu (One-to-One Evaluation)}

Evaluasi satu-satu (one-to-one) dilakukan dengan tiga orang mahasiswa dari kelas A.2.1 mahasiswa yang dipilih mewakili kemampuan tinggi, sedang dan rendah. Dari angket yang diberikan pada saat evaluasi one-to-one terlihat bahwa 2 orang mahasiswa memberikan respon yang Sangat Baik dan 1 orang mahasiswa memberikan respon Baik. Tanggapan mahasiswa terhadap Prototipe I dapat dilihat pada gambar 2 berikut: 


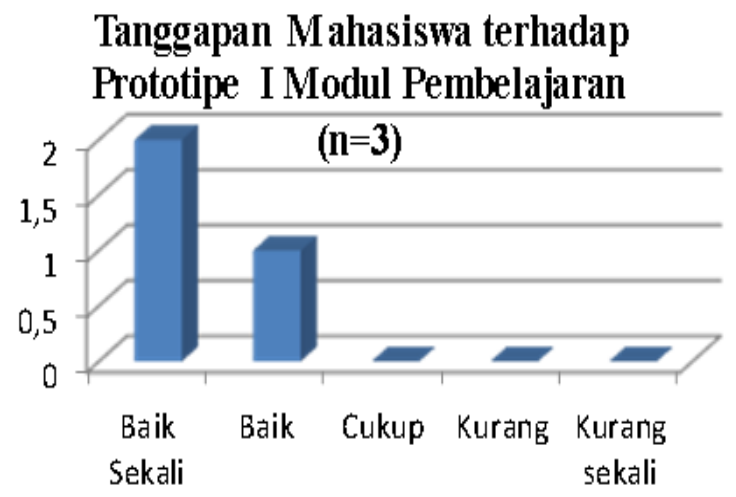

\section{Gambar 2 Diagram Batang Tanggapan mahasiswa terhadap Prototipe I pengembangan modul}

\section{Evaluasi kelompok kecil (small group)}

Evaluasi Kelompok kecil (small group) dilakukan dengan sepuluh orang mahasiswa dari kelas A.2.1. Pemilihan mahasiswa didasarkan pada kemampuan mahasiswa, yang mewakili karakter mahasiswa yang akan menjadi objek penelitian. Pengembangan modul pembelajaran yang digunakan pada tahap ini adalah prototipe II yang merupakan hasil revisi prototipe I berdasarkan evaluasi dari ahli (expert review) dan evaluasi satu-satu (one to one). Permasalahan yang ditemukan pada evaluasi one-to-one tidak lagi ditemukan. Hal ini berarti bahwa prototipe II sudah memenuhi kriteria sebagai modul pembelajaran yang praktis. Dari angket yang diberikan pada saat evaluasi small group terlihat bahwa 10 mahasiswa memberikan respon yang Sangat Baik. Tanggapan mahasiswa terhadap Prototipe II dapat dilihat pada gambar 3 berikut:

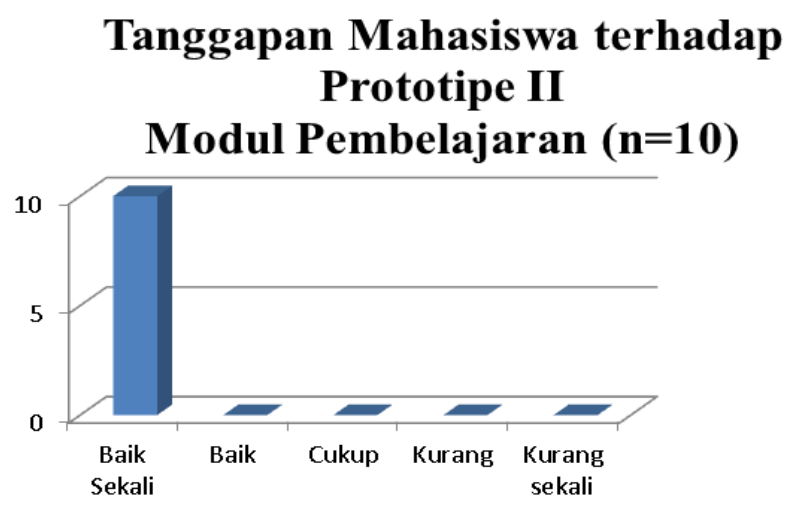

Gambar 3 Diagram Batang Tanggapan mahasiswa terhadap Prototipe II pengembangan modul 


\section{Uji Coba Lapangan (Field Test).}

Pada tahap ini, prototipe III yang sudah dikembangkan, diujicobakan setelah melalui validasi akhir pada pakar. Ujicoba lapangan (Field Test) dilakukan untuk melihat efek potensial terhadap motivasi belajar mahasiswa. Ujicoba ini dilaksanakan pada kelas A.2.1. Pada pelaksanaan pembelajaran menggunakan modul di ruangan belajar 17. Tanggapan mahasiswa pada pelaksanaan uji lapangan (field test) telah memberikan tanggapan positif terhadap prototipe III. Pada proses pembelajaran 15 orang mahasiswa (80\%) memberikan tanggapan sangat baik dan 5 orang mahasiswa (20\%) memberikan tanggapan baik. Tanggapan mahasiswa terhadap Prototipe III dapat dilihat pada gambar 4 berikut:

Tanggapan Mahasis wa te hadap Prototipe III Modul Pembelajaran $(\mathrm{n}=20)$

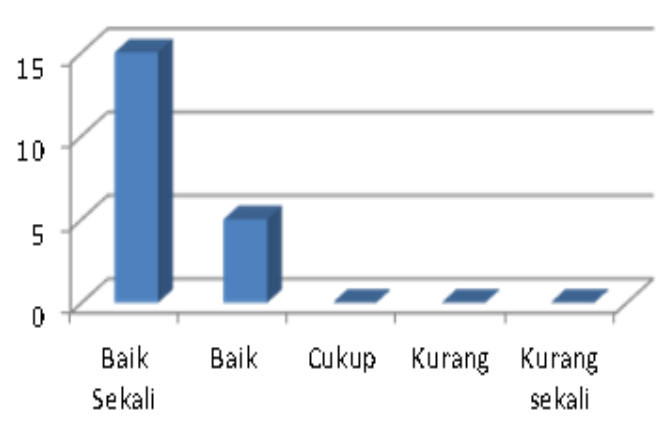

Gambar 4 Diagram Batang Tanggapan mahasiswa terhadap Prototipe III

\section{B. Pembahasan} pengembangan modul

Penelitian pengembangan ini menghasilkan modul pembelajaran pada mata kuliah Strategi belajar dan Pembelajaran. Pengembangan modul yang dihasilkan telah teruji validitasnya. Berdasarkan hasil uji validasi dari expert (pakar) menunjukkan bahwa pengembangan modul yang dikembangkan sudah memenuhi syarat dari aspek materi dan sesuai dengan aspek-aspek yang diinginkan dari segi media dan desain pembelajaran. Validator materi memberikan penilaian terhadap pengembangan modul yang dihasilkan dengan rata-rata penilaian 4,5 (valid). Menurut validator, pengembangan modul sudah memenuhi syarat sebagai pengembangan bahan ajar yang baik dari seluruh aspek yang dinilai. Unsur-unsur pengembangan modul berupa materi, dan gambar, sudah dipenuhi dan disajikan 
dengan baik di dalam pengembangan modul ini. Revisi yang dilakukan terhadap prototipe I ini berasal dari validator Materi, Desain dan Media.

Beberapa revisi dilakukan untuk memberikan pemahaman konsep yang utuh tentang kejelasan materi dan kemudahan penggunaan pengembangan modul menurut validator, pengembangan modul sudah harus dikenalkan dari semester awal. Hal yang perlu diperhatikan adalah memilih batasan-batasan konsep dasar yang diajarkan pada tingkat pendidikan perguruan tinggi. Masukan dari validator sangat berarti bagi peneliti untuk menentukan batasan konsep tersebut. Validasi aspek desain pembelajaran, Validator desain pembelajaran berdasarkan kurikulum memberikan penilaian terhadap pengembangan modul yang dihasilkan dengan ratarata penilaian 4,5 (valid). Validator media memberikan penilaian terhadap pengembangan modul yang dihasilkan dengan rata-rata penilaian 4,2 (valid). Dengan demikian, dapat dikatakan bahwa pengembangan bahan ajar yang dikembangkan sudah baik dan tergolong prototipe yang valid.

\section{Kesimpulan}

Berdasarkan hasil penelitian, telah dihasilkan pengembangan modul pada mata kuliah Strategi Belajar dan Pembelajaran yang teruji validitasnya. Pengembangan modul yang dihasilkan dari aspek materi sudah tepat dengan pembelajaran, menggunakan media cetak, gambar yang tepat, dan jelas dalam uraian materi, soal latihan dan soal evaluasi. Dari aspek desain pembelajaran, Pengembangan modul yang dihasilkan memiliki kesesuaian pendekatan dalam pembelajaran, efektif dan efisien dalam pencapaian kompetensi, sesuai dengan karakteristik sasaran, soal latihan dan soal evaluasi sesuai dengan RPS.

Dari aspek media modul yang dihasilkan memiliki kemenarikan dan kemudahan dalam memahami materi sehingga diharapkan dapat mendorong mahasiswa untuk lebih termotivasi dalam belajar. Berdasarkan hasil penelitian, telah dihasilkan modul pada mata kuliah Strategi Belajar dan Pembelajaran pada Program Studi Teknologi Pendidikan Universitas Baturaja. Modul yang dihasilkan menarik bagi mahasiswa, dan mudah dipahami. Dari hasil uji coba lapangan kepada mahasiswa kelas A.2.1 semester 2 menunjukkan bahwa perkuliahan pada mata kuliah Strategi Belajar 
Nora Agustina dan Anita Adesti

dan Pembelajaran menggunakan modul dapat meningkatkan aktivitas belajar mahasiswa. 


\section{BIBLIOGRAFI}

Dahar, R. W. (2011). Teori-teori belajar dan pembelajaran. Jakarta: Erlangga, 136, 141.

Esmiyati, E., Haryani, S., \& Purwantoyo, E. (2013). Pengembangan Modul IPA Terpadu Bervisi SETS (Science, Environment, Technology, and Society) Pada Tema Ekosistem. Unnes Science Education Journal, 2(1).

Gani, M. A. (2018). Pengaruh Disiplin Diri Dan Motivasi Belajar Terhadap Prestasi Belajar Mahasiswa Akademi Maritim Cirebon. Syntax Literate; Jurnal Ilmiah Indonesia, 3(2), 82-93.

PMPTK, D. (2008). Penulisan Modul. Jakarta: Depdiknas.

Prastowo, A. (2011). Panduan kreatif membuat bahan ajar inovatif. Yogyakarta: DIVA press.

Suryosubroto, B. (1983). Sistem pengajaran dengan modul. Jakarta: Bina Aksara.

Tessmer, M (1993) Planning and Conducting Formatif Evaluation, London : Kogan Page

Tjiptiany, E. N., As'ari, A. R., \& Muksar, M. (2016). Pengembangan Modul Pembelajaran Matematika dengan Pendekatan Inkuiri untuk Membantu Siswa SMA Kelas X dalam Memahami Materi Peluang. Jurnal Pendidikan: Teori, Penelitian, Dan Pengembangan, 1(10), 1938-1942.

Warsita, B. (2008). Teknologi pembelajaran landasan dan aplikasinya. Jakarta: Rineka Cipta, 135.

Wedman, J., \& Tessmer, M. (1993). Instructional designers decisions and priorities: A survey of design practice. Performance Improvement Quarterly, 6(2), 43-57.

Zulkardi, Z. (2002). Developing a learning environment on realistic mathematics education for Indonesian student teachers. University of Twente, Enschede. 